firmly that "it is reactions that catalyse, not substances".

After the First World War he turned his attention to the reaction complex of the acids and oxides of nitrogen and sulphur, and contributed a number of papers on the mechanism of the reactions in the lead chamber process for the production of sulphuric acid. $\mathrm{He}$ also continued his work on the mechanism of oxidation-reduction reactions and studied the isotope effect in kinetics. During the Second World War he worked on industrial problems of national importance and projected a study of the basic mechanism of the dry cell; he worked on this until his retirement. Even afterwards he did not remain idle: he considered different kinetic mechanisms from a unified point of view in which electron transfer reactions play a central part.

Abel had established a large and vigorous school in Vienna, and his institute produced work on many branches of physical chemistry. He had a peculiar, racy style of lecturing, which was appreciated more by the élite than the average student.

$\mathrm{He}$ took little active part in matters outside science, but had by no means the narrow outlook of the specialist ; those who had the pleasure of hearing his talks to the Austrian Club in London can testify to this. He had an uncomplicated, pleasant nature; though he continued to live in London after the War, he always had a great love for Austria. His eightieth birthday was the occasion for special celebrations by the Academy of Sciences in Vienna and the Bunsengesellschaft.

His two children of his first marriage, and his second wife, survive him.

H. TOMPA

\section{Dr. J. S. Farquharson}

THE meteorological service of Great Britain lost a well-known and senior member of its staff, when Dr. James Strachan Farquharson lost his life in a fatal motoring accident on January 31. Dr. Farquharson was born on June 30, 1904, and joined the Meteorological Office in July 1925 after graduation in the University of Aberdeen. $\mathrm{He}$ served in various divisions of the Meteorological Office, mainly those concerned with meeting the requirements of civil aviation and the Royal Air Force, both at home and overseas. In June 1954, Dr. Farquharson was appointed as assistant director for public services and, in this capacity, did much to develop both the television and weather broadcasts and the automatic telephone weather service in Britain.

The death of Dr. Farquharson was also a sad loss to the Royal Meteorological Society, of which he had been a Fellow since 1934. As honorary treasurer of the Society, he succeeded in introducing a modification of the old-established policy of investing in gilt-edged securities-a change which he firmly believed will prove of considerable value to the Society. His contributions to the Society's Quarterly Journal included two studies related to the development of Empire air routes, namely, "Haboobs and Instability in the Sudan" and "The Diurnal Variation of Wind over Tropical Africa".

The death of Dr. Farquharson has brought to an untimely end an experienced and energetic personality with a wide comprehension of, and original ideas for meeting, the meteorological requirements of the community.

\author{
Mr. F. J. Welch
}

THE death on May 7 of Mr. F. J. Welch, for forty-six years an assistant in the George Holt Physics Laboratory of the University of Liverpool, has severed one of the few remaining links of personal association with Sir Oliver Lodge, Lyon Jones professor of physics in 1900. Mr. Welch was then only in his early twenties, but his recollections of the great man-and his wireless aerial-were very vivid.

Prof. Wilberforce followed Sir Oliver and held the chair for thirty-five years, and Mr. Welch became senior laboratory steward during this period. Those were the days when popular lectures were delivered on "Liquid Air", and also when medical as well as science students attended lectures and demonstrations in physics, which brought them all into intimate contact, not only with the teaching staff, but also with Mr. Welch, who acted as demonstrator. Many physicists, medical men, dentists and school teachers now scattered all over Britain will have happy recollections of the kind and helpful way he always had with them at these classes.

Sir James Chadwick became professor of physics in 1935, and until he retired in 1946, Mr. Welch was in the Department and experienced the period of secrecy which followed the splitting of the atom; and he had close contact with other well-known physicists, such as Prof. J. Rotblat and Prof. O. R. Frisch.

It is interesting to note that his eldest son, E. A. Welch, who received his early training in the George Holt Physics Department, is now senior technician in the Department of Physics, University College of North Wales, Bangor. W. J. Pierce

\section{Mr. G. A. Cook}

Mr. George Alfred Cook died suddenly in Melbourne on January 4. He had enjoyed a comparatively brief retirement from the Commonwealth Scientific and Industrial Research Organization, of which he had been secretary during 1944-52. Before the First World War, Cook was an outstanding student at Ormond College in the University of Melbourne and graduated with first-class honours as master of science and bachelor of mining engineering. During the War he was commissioned in the Second Australian Tunnellers, in which unit he gave distinguished service in France and was awarded the Military Cross.

After the War he spent several years in research work in the mining industry, and in 1922 joined the Institute of Science and Industry as a scientific abstractor. The Institute was replaced by the Council for Scientific and Industrial Research, which in turn was succeeded by the Commonwealth Scientific and Industrial Research Organization, and Cook's service with these bodies was continuous. When he joined the Institute in 1922 there were only two people with scientific training on the staff. When he retired as secretary of the Organization, there was a total staff of more than three thousand, of whom one thousand held professional qualifications. Cook, during his early years with the Organization, took a particular interest in making the results of scientific research available to industry, both as an editor of scientific publications and as a writer of non-technical accounts for the general reader. 